\title{
Ergenlerde Öfkeyle Olumlu Baş Etme: Akran Baskısı, Arkadaş Bağglılığı, Algılanan Sosyal Destek ve Cinsiyetin Rolü
}

\author{
Positive Coping with Anger of Adolescents: The Role of \\ Peer Pressure, Friend Attachment, Perceived Social Support \\ and Gender
}

\author{
Sezai DEMIR*, Öner ÇELIKKALELI***
}

\begin{abstract}
Öz: Bu araştırmanın amacı ergenlerin okulda öfkelerini olumlu ifade biçimi ile akran baskısı, arkadaş bağlılı̆̆ı, algılanan sosyal destek ve cinsiyetleri arasındaki ilişkileri ortaya koymaktır. Bu amaçla, 544 lise öğrencisinden veri toplamıştır ( $326 \mathrm{kız}, 218$ erkek). Bu ergenlerin yaşlarının ortalaması 16.10 (sd: .90) olarak elde edilmiştir. Araştırmada veri toplama araçları olarak, Çok Boyutlu Okul Öfke Envanteri, Arkadaş Bağlılık Ölçeği, Akran Baskısı Ölçeği ve Demografik Bilgi Formu kullanılmıştır. Araştırma sonucundaki bulgulara göre, okulda öfkeyi ifade etme biçimi puanları ile akran baskısı puanları ve arkadaş bağlılığı puanları arasında pozitif yönde anlamlı ilişkiler elde edilmişken, akran baskısı puanları ile arkadaş bağlılığı puanları arasında negatif yönde anlamlı bir ilişsi bulunmaktadır. Diğer taraftan, akran baskısı, algılanan sosyal destek, arkadaş bağlılı̆g ve cinsiyetin okulda öfkeyi olumlu biçimde ifade etme puanlarını anlamlı bir biçimde yordadığı görülmüş̧ür. Ayrıca, erkek ergenlerin okulda öfkelerini kız öğrencilere göre daha olumlu ifade ettikleri görülmüştür. Son olarak da algılanan sosyal desteğin ergenlerin öfkelerini olumlu ifade etmelerinde önemli bir faktör olduğu bulgusuna ulaşılmıştır. Elde edilen bulgular literatür ışı̆̆ında tartışılmış, yorumlanmış ve önerilerde bulunulmuştur.
\end{abstract}

Anahtar Kelimeler: Öfke, öfke ifade, akran baskısı, arkadaş bağl1lığı, sosyal destek

\begin{abstract}
The aim of this study is to reveal the relationship between adolescents' positive expression of anger at school and peer pressure, friends attachment, perceived social support and gender. For this purpose, data were collected from 544 high school students (326 female, 218 male).The mean age of these adolescents was 16.10 (sd: .90).Multidimensional School Anger Inventory, Friend Attachment Scale, Peer Pressure Scale and Demographic Information Form were used as data collection tools. According to the findings of the study, there was a positive relationship between peer pressure scores and peer pressure scores and peer commitment scores, while peer pressure scores were negatively correlated with peer pressure scores. On the other hand peer pressure, perceived social support, friendship and gender predictingpositively expression of anger at school scores. In addition, it was seen that male adolescents expressed their anger more positively in school than female students.Finally, it was concluded that perceived social support was an important factor in the positive expression of anger among adolescents.The findings were discussed, interpreted and suggested in the light of the literature.
\end{abstract}

Keywords: Anger, anger expression, peer pressure, friend attachment, social support

\section{Giriş}

Ergenlik dönemi, sosyal bilimlerde birçok araştırmaya, içerdiği gelişimsel özellikler ve yaşamsal süreçlerden dolayı, konu olmuştur. Özellikle bu dönemde, ergenlerin kimlik arayışı ve bağımsızlık girişimleri onu aile dışında da bir çevre kurmaya yöneltmektedir. Aile dışında kurulan çevre ergenlerin duygusal durumları üzerinde de etkili olmaktadır. Arkadaş, okul çevresi, yoğun yaşanan duygular ve bu duyguları ifade edebilme onun çevresiyle kurduğu ilişkilerde önemli rol oynamaktadır. Kurduğu ilişiklilerin niteliğini belirlemede ise birçok kavram etkilidir. Bunlardan birisi de yoğun yaşadığı duyguların ifadesi ve dolayısıyla bu

*Dr. Öğr. Üyesi, Hatay Mustafa Kemal Üniversitesi, Eğitim Fakültesi, Hatay-Türkiye, ORCID: 0000-0002-77674105, e-posta: demirsezai01@gmail.com

**Doç.Dr., Muğla Sıtkı Koçman Üniversitesi, Eğitim Fakültesi, Muğla-Türkiye,: 0000-0003-0210-3647, e-posta: celikkaleli@gmail.com 
duygulardan birisi olan öfkesini nasıl ifade ettiğidir (Fryxell ve Smith, 2000; Smith, Furlong ve Boman, 2006).

Aile içi ilişkilerde, okullarda, yaşam içerisinde öfke kaynaklı birçok problemler göze çarpmaktadır. Özellikle öğrencilerin, öfke ifade biçimlerinin incelenmesi ele alınması önemlidir. Çünkü öfkenin olumsuz ifade edilmesi birçok sosyal uyum problemine yol açmaktadır (Feindler ve Engel, 2011). Öğrencilerin okul yaşantısında uyumlarını belirleyici (Fryxell ve Smith, 2000) kavramlardan birisi olan öfke, engellenme, haksızlığa uğrama, küçümsenme durumunda ortaya çıkan bir duygu olarak tanımlanarak (Spielberger, 1998; Torestad, 1990), duygusal, davranışsal ve bilişsel olarak dört farklı boyutta ele alınmıştır (Spielberg, 1998). Öfkenin duygusal boyutu; duyguların yoğunluğu, davranışsal boyutu; öfkeyi ifade etmedeki tutumlar, bilişsel boyutu; kişilere ve olaylara karşı geliştirdiği inanç ve fiziksel boyutu ise vücudunda medya gelen psikosomatik değişimlerle ilgilidir (Taylor ve Novaco, 2005). Öfke, görüldüğü üzere sadece duygusal açıdan değil; aynı zamanda bilişsel ve davranışçı boyut bakımından da ele alınmaktadır (Spielberg, 1998; Spielberger, Johnson, Russell ve Crane, 1985). Bu bakımdan, duygusal, bilişsel, fiziksel ve davranışçı boyutlarla açıklanan öfkenin yoğun yaşanması ya da ifade edilme şekli kişinin yaşantılarına ve karakteristik özelliklerine göre değişmektedir (Spielberger, Johnson, Russell ve Crane, 1985).

Öfke yaşanma düzeyi, kişisel yaşantılara ve karakteristik özelliklere göre farklılaştığına göre bazen olumlu bazen de yıkıcı şekilde ifade edildiği gözlemlenebilmektedir. (Smith, Furlong, Bates ve Laughlin, 1998). Elliot ve Smith'e (2017) göre, öfkenin olumsuz ifade edilmesinde, sözlü şiddet, sözlü olmayan şiddet, öfkeyi baskılamak, pasif saldırgan davranmak, şikâyet etmek, fiziksel saldırganlık ve yer değiştirme gibi tutumlar kullanılmaktadır. Bağırma, tartışma, incitici söz kullanma sözel şiddet; yüzdeki öfke mimikleri, yumruk sıkma, düşmanca bakmak, sözel olmayan şiddet içerikli davranışlardır. Öfkeyi yaşamayarak bunu somatize etmek (yüksek tansiyon, sindirim sorunları vb.) öfkeyi baskılamak; saldırmak, itip kalkmak, fiziksel acı vermeye yönelik davranışlar, fiziksel saldırganlık; öfkeyi eşya veya ilgisiz daha savunmasız kişilere yöneltmek de yer değiştirme olarak tanımlanmaktadır. Öfke duyulan kişiyi başkasına şikâyet etmek, onun hakkında konuşmak; kasten unutmak, ertelemek, gecikmek ise pasif saldırgan öfke davranışlarıdır (Elliot ve Smith, 2017).

Öfke, ayrıca içe ve dışa yönelik olarak ifade edilmektedir. Özellikle dışa yönelik öfke ifadesinin olumlu veya olumsuz olması bireyin ilişkilerinde, kabul edilmesinde önemli rol oynamaktadır (Smith ve Furlong, 1994). Öfkenin ifadesi bireysel özelliklere göre değişebildiğine göre, bu değiş̧ikliklerde kültürel özellikler, okulda kendini güvende hissetme, yaşantılar, rol model kişiler etkili olmaktadır. Bazı öğrenciler, öfkelerini ifade ederken diğerlerine karşı saldırgan, düşmanca tavırlar içerisinde olabilmektedir (Fryxell ve Smith, 2000). Öğrenciler, özellikle ergenler için, eğitim veya okul çevresi birçok açıdan stres kaynaklı yaşantılarla doludur. Bu yüzden ergenler okul ortamında öfke duygusunu yoğun şekilde yaşama riskine sahiptir (Fryxell ve Smith, 2000). Okul yaşantısı sürecinde görülen öfke, davranışsal, sosyal, akademik ve fiziksel kaygılarla ilişkilidir (Smith ve Furlong, 1994). Bu açıdan bakıldığında yaşam problemleriyle baş etmedeki zorluk, bireyi stres altına almakta, duygusal durumunda etkili olup, öfkesini nasıl ifade edeceğinde belirleyici olmaktadır. Bu yaşam problemlerinden birisi de sosyal kaygılarla baş etmektir. Sosyal kaygılarla baş etmede iki faktör vardır. Birisi sosyal destek diğeri de arkadaş ve akranlarıyla olan ilişkilerdir (Cohen ve Wills, 1985).

Sosyal destek, ergenler için, sosyal ve destek sistemleri içerisinde algılanması, niteliği ve düzeyi açısından önemlidir. Desteğin en önemli boyutu ise yakın çevreden alınanıdır (Chappell ve Funk, 2011). Sosyal destek alabilen bireyler, duygusal bağlarını ve yakınlığını güçlendirdiği için olumsuz duygularını daha kontrollü yaşayabilmektedir(Feindler ve Engel, 2011). Literatüre göre; sosyal desteğin çocuk veya ergen üzerindeki etkisi ile ilgili çalışmalar 1970'lere kadar dayanmaktadır. Bu çalışmalardan Cobb (1976), Zimet ve diğerleri, (1988), sosyal ilişkilerin, yaşam boyunca bireyin yeni kaynaklara ulaşma, stresle baş etme, yaşam rollerini kabullenebilme ve değişen yaşam şartlarına uyabilme açısından önemli avantajlar sağladığını öne sürmektedir. 
Sosyal desteğin algılanan ve verilen sosyal destek şeklinde iki farklı boyutu vardır. Algılanan sosyal destek, bireyin kendi varlığını gösterebilmesi ve bu varlığının dışarıdan (aile, arkadaş ve yakın çevresi) memnun edici şekilde desteklenmesidir (Gottlieb ve Bergen, 2010). Algılanan sosyal destekte aile, arkadaş, yakın çevre ve öğretmen gibi algı kaynakları birbirinin yerine geçemez (Uchino, 2009). Verilen sosyal destekte çocuk dışarıya bağlı olurken, sosyal desteği algılayan kişi ise çevreden gelen destek kaynaklarını kullanabilir ve nitelikli bir kişiler arası yaklaşıma sahip olur. Verilen ve algılanan sosyal destek ebeveyn çocuk ilişkisinde farklı stratejilerle altında ele alınabilir. Bu nedenle çocuklar ya da ergenler, algılanan sosyal desteği aile içinde ebeveynlerinden aldıkları desteğe ve iletişim örüntülerine göre belirlerler. Algılanan sosyal destek, bir model veya iletişim kalıbı olarak birine faydalı etkileşimleri içeren örüntülerdir. Sosyal destek ile bu desteğin algılanması arasındaki en önemli fark, sosyal desteğin birey tarafından hissedilerek psikolojik açıdan destek sağlamasıdır (Schafer, Coyne ve Lazarus, 1981).

Bununla beraber sosyal destek, bireyler üzerinde stresle doğrudan ilişkili olarak iki sonuca neden olmaktadır. İlki bireylerin çevresinden algıladığı sosyal destek daha az stres yaşamasına; ikinci ise bireyin yaşam problemleriyle baş etmesine yardımcı olmaktadır. Bu sayede birey daha sağlıklı davranışlar sergileyebilmektedir. Sosyal destek, bu sayede bireyin duygusal durumunu düzenleyerek sağlıklı ve uyumlu davranışlar sergilemesine neden olmaktadır (Cohen ve Wills, 1985; Cohen, Gottlieb ve Underwood, 2000). Ayrıca sosyal yap1 içerisindeki ilişkiler, bireyin fiziksel ve psikolojik açısından kendisini iyi hissetmesinde etkilidir (Thoits, 1985; Uchino, Cacioppo ve Kiecolt-Glaser, 1996). Algilanan sosyal destek, birey üzerinde yakın çevreden, aileden, arkadaşlardan ve öğretmenlerden saygı görmek, kabul edilmek gibi olumlu duyguların oluşmasına neden olur (Zimet ve diğerleri, 1988). Dolayısıyla algılanan sosyal desteğin ergenlerin öfkelerini olumlu ifade etmelerinde önemli bir rol oynayabileceği düşünülmektedir.

Cohen ve Wills (1985), ergenlerin öfkelerini ifade etmede önemli belirleyicilerden birisinin de arkadaşlarıyla ilişkilerinin niteliği olduğunu belirtmiştir. Ergenler için gelişim dönemleri gereği bir gruba dâhil olmak ve o grup tarafından kabul görmek ihtiyacını hissederler ve bu gelişimsel özellik ergenlik döneminde arkadaşlık ve arkadaş bağlığını önemli hale getirir (Bee ve Boyd, 2009). Özellikle okul sürecinde ergenler için arkadaşlara bağlılık daha önemli hale gelmektedir. Öğrencilerin arkadaşlarıyla ilişkileri onların duygusal durumuna, diğer ilişkilerine ve dönemsel özelliklerine etki etmektedir (Vanderdrift, Lehmiller ve Kelly, 2012). Ergenlerin duygularını düzenleyebilmesi onların sosyal gelişimleri ile ilişkilidir. Duygularını olumlu ifade edebilen çocuklar daha nitelikli ilişkiler kurabilmekteyken (Eisenberg ve diğerleri, 1995), arkadaşlarıyla yakın ilişkiler kurabilen ve onlara karşı bağlılıklarını güçlendiren bireyler, öfkelerini daha olumlu ifade edebilmektedir (Feindler ve Engel, 2011).

Akran ilişkilerinin niteliği, öğrencilerin okul ortamındaki öfke ve saldırganlık davranışları üzerinde önemli rol oynamakta olup, öfkenin ifade edilmesinde akran ve arkadaş ilişkileri de önemli bir belirleyicidir. Sosyal beceri eksikliği veya çok az arkadaşa sahip olan bireyler ise öfkelerini daha olumsuz bir şekilde ifade edip, düşmanca davranışlar sergilemeye daha yatkındırlar (Fryxell ve Smith, 2000). Öfke, özellikle saldırgan yollarla ifade edildiği zaman diğer insanlarla olan iletişimi mesafeli hale getirir, iletişimin sağlıklı olmasına engel olur (Eisenberg ve diğerleri, 1995). Öfkelerini olumlu veya duygularını ifade etmede başarısızlık yaşayan öğrencilerin, arkadaş veya akranları tarafından kabul edilmesi de bir o derecede de başarısız olmakta ve arkadaşları tarafindan kendilerine yönelik olumsuz duygular beslenmektedir (Eisenberg ve diğerleri, 1995).

Ergenlerin arkadaşlarıyla arasındaki ilişki örüntülerini belirleyen önemli noktalardan birisi de onlardan etkilenme ve etkileme düzeyidir. Bu bağlamda akranlarıyla iletişime geçerek onlarla ilişkisini zenginleştirmek isteyen ergen aynı zamanda akran veya akran grubundan kabul görmek için onların isteklerini kabul eder (Blakemore ve Mills, 2014; De Guzman, 2009) Bu etkilenme düzeyinde akran baskısı önemli etkendir (Blakemore ve Mills, 2014; Coyne ve Downey, 1991; Goel ve Malik, 2017). Akran baskısı ergenlerin arkadaşlarından veya arkadaşından hissettiği etkiler olarak tanımlanmaktadır (Goel ve Malik, 2017; De Guzman, 
2009). Akran baskısı, bir ergenin veya bir grubun diğerine madde kullanma, olumsuz veya uyumsuz davranışa cesaretlendirme, aynı model giyinme, aynı müzikleri dinleme, seksüel faaliyetlere ve aile bilgisi dışındaki eğlenmeye özendirme gibi çeşitli şekillerdeki olumsuz davranışlarını içerebilir (Goel ve Malik, 2017; Maxwell, 2002; Santor, Messervey ve Kusumakar, 2000; Shilts, 1991). Aynı zamanda akran baskısına maruz kalan birey, içinde bulunduğu grubun baskısı ve aksi durumda onlar tarafından dışlanacağını düşündüğü için sonunu düşünmeden risk içeren davranışlar sergileyebilir. Ergen tarafından risk alınarak yapılan davranışlar sosyal gelişimlerinin önemli bir göstergesi olarak kabul edilir (Goel ve Malik, 2017). Ergenlerin akran baskısına maruz kalarak yaptığ 1 davranışlar, gruba bağlılık açısından dürüstlük, gruba kabul, samimiyet ve içtenlik göstergesi olarak kabul edilir (Maxwell, 2002).

Öfke ifade biçimleriyle, cinsiyet, algılanan sosyal destek, arkadaş bağlılığ 1 ve akran baskısı değişkenlerini içeren çalışmalar incelediğinde aşağıdaki bulgulara ulaşılmıştır:

Civitci (2011) okul öfkesini ifade etmede okula yabancılaşma ve algılanan desteğin ne düzeyde katkısı olduğunu belirlemek için yaptığı çalışmada 201'i kız ve 299'u erkekten oluşan 500 lise öğrencisine çok boyutlu öfke, algılanan sosyal destek ve okula yabancılaşma ölçeğini uygulamıştır. Elde edilen çoklu regresyon analizi verilerine göre öfke yaşantısı, düşmanlık ve yıkıcı ifade, okula yabancılaşma tarafından pozitif yönde yordanmıştır. Ayrıca öfkenin yıkıcı ifadesini sırayla aile, arkadaş ve öğretmen sosyal desteğinin yordadığı sonucuna ulaşmıştır. Yine yapılan regresyon sonuçlarına göre öfkenin yıkıcı ifadesini pozitif anlamda yordarken, ögretmen ve aileden alınan sosyal desteği negatif düzeyde yordamıştır. Öfkeyle olumlu baş etmenin en güçlü yordayıcısı olarak öğretmenlerden algılanan sosyal destek olduğu belirtilmiştir.

Saçar (2007), yapmış olduğu yüksek lisans tez çalışmasında ilköğretim sekizinci sınıfa devam eden öğrencilerin öfke tepkisiyle arkadaş bağll1ı̆̆ının incelemiştir. Araştırma sonucunda öğrencilerin sürekli öfke düzeyleri, içe ve dışa yönelik olan öfke puanları ile arkadaş bağl1lığı puanları arasında anlamlı bir ilişki bulunamamıştır. Fakat öfke düzeyi düşük olan öğrencilerin, öfke düzeyi orta ve yüksek olanlara göre arkadaşlarına yüksek düzeyde bağlı olduğu sunucunu da ulaşılmıştır.

Hernawati, Rahayu ve Soejowinoto (2015) Endonezya'da 11. sinıf öğrencileriyle yapmış oldukları çalışma sonucunda okul öfke ifade biçimleriyle arkadaş ve anne-baba bağlılığ arasında negatif yönde ilişki, okul öfke ifade biçimleriyle akran baskısı arasında ise pozitif yönde ilişki bulmuşlardır.

Smith ve Thomas (2000) ise öfkesini şiddet yoluyla gösteren öğrencilerin aileden yeteri kadar destek alamadığını, bu öğrencilerin okul ortamını adil bulmadıkları ve somatik öfke belirtileri sonucuna ulaşmışlardır. Ayrıca araştırma sonuçları, öfkesini içe yönelten öğrencilerin ise bulundukları ilişkisel ve okul durumundan memnun olmadıklarını ortaya koymuştur.

Erdur-Baker ve diğerleri ergenlerin cinsiyet değişkenine göre gösterdiği öfke tepkileri arasında anlamlı bir fark olup olmadığını belirlemeye yönelik elde edilen bulgularda; öfke kontrolünde, öfkenin dışavurumunda erkeklerin lehine, öfkenin içte yaşanmasında ise kızların lehine anlamlı fark ortaya çıkmıştır.

Boman, (2003) Avustralya'da öfke tepkilerine ilişkin ölçek geliştirme çalışmasında kızlarla erkekler arasında öfkenin davranışsal boyutta ifade edilmesinde kızların lehine anlamlı bir fark bulmuştur.

Evren ve diğerleri (2015) saldırgan ve öfkeli davranışlarda kızların lehine anlamlı farkın olduğunu bulmuşlardır.

Ghanizadeh (2008), okuldaki öfke biçimlerini cinsiyete ve intihara eğilimli davranışlara göre incelemiş, öfke ifade biçiminde erkeklerin lehine, öfkeyle olumlu baş etmede cinsiyet anlamında anlamlı bir farklılık bulamamıştır

Literatür ve ilgili çalışmalar incelendiğinde, ergenlerin öfkelerini ifade biçimlerinin, onlar için önemli olan aile, arkadaş gibi sosyal ilişkiler örüntüsünde önemli bir değişken olduğu göze çarpmaktadır. Ayrıca, öfkenin öğrencilerin kontrol ve ifade etmesi gereken en önemli duygulardan birisi olan öfkenin (Philips-Hershey ve Kanagy, 1996), öğrencilerin özellikle okul ortamındaki yaşantılarının kaynaklık ettiği için bu duygunun sonuçlarını ortaya koymak ve 
incelemek önem kazanmaktadır. Buna göre araştırmamızın amacı, ergenlerin okulda öfkelerini olumlu ifade etmelerini incelemektir. Bu amaca uygun olarak aşağıdaki sorulara cevap aranmıştır:

- Ergenlerin okulda öfkeleriyle olumlu baş etme biçimleri, akran baskısı ve arkadaş bağl1lıkları arasında ilişki var mıdır?

- Ergenlerin akran baskıları, algılanan sosyal destek kaynakları, arkadaş bağlılıkları ve cinsiyetleri okulda öfkeyi ifade etme biçimini yordamakta mıdır?

- Ergenlerin okulda öfkeleriyle olumlu baş etme biçimleri cinsiyetlerine göre farklılaşmakta mıdır?

- Ergenlerin okulda öfkeleriyle olumlu baş etme biçimleri algıladıkları sosyal destek kaynaklarına göre farklılaşmakta mıdır?

\section{Yöntem}

Bu bölümde araştırma süreci ile ilgili araştırma deseni, araştırmanın çalışma grubu, araştırmada kullanılan veri toplama araçları ve verilerin analizi ile ilgili bilgiler yer almaktadır.

\section{Araştırma deseni}

Araştırmada nicel araştırma desenlerinden ilişkisel tarama modeli kullanılmıştır. Araştırmada bağımlı değişken olan ergenlerin olumlu öfke ifade biçimi ile bağımsız değişkenler; akran baskısı, algılanan sosyal destek, arkadaş bağlığ ve cinsiyet değişkenleri arasındaki ilişki ortaya konulmaya çalışılmış̧ır. İlişkisel tarama, birden fazla değişken arasındaki toplam değişimi veya değişim düzeyini belirlemeyi amaçlamaktadır. İlişkiyi ortaya koyama yönelik betimlemeler, var olan durumun belli standartlara uyan ölçülerini bulmaz; birey, durum, nesne ve tutum arasındaki ayrımların belirlenebilmesine yaramaktadır (Karasar, 2014).

\section{Çalışma grubu}

$\mathrm{Bu}$ çalışma çerçevesinde, 610 lise öğrencisine ulaşılmıştır. Verilerin incelenmesi sonucunda 544 kişinin doldurmuş olduğu veri seti üzerinden çalışma yürütülmüştür. 66 veri ise eksik olduğu için çalışmadan çıkarılmıştır. Araştırmaya katılan öğrencilerden 326's1 $(\% 59,92)$ kız, 218'i $(\% 40.08)$ ise erkektir. Bu öğrencilerin yaş ortalaması ise 16.10 'dır (.90)

\section{Veri toplama araçları}

Araștırmada ergenlerin okulda öfkelerini olumlu öfke ifade etme durumunu belirlemek için Çok Boyutlu Okul Öfke Envanteri'nin Öfkeyle Olumlu Başetme alt ölçeği, arkadaş bağlılığı düzeyi için "Arkadaş Bağlılık Ölçeği”", akran baskısı puanlarını belirlemek için "Akran Baskısı Ölçeğì", cinsiyet ve algılanan sosyal destek kategorisi için ise araştırmacılar tarafindan düzenlenen Demografik Bilgi Formu kullanılmıştır.

Çok Boyutlu Okul Öfke Envanteri: Bu ölçme aracının özgün formu Smith, Furlong, Bates ve Laughlin (1998) tarafından geliştirilmiştir. Ölçme aracı, Likert tipi olup 1-4 arasında puanlanmaktadır. Ölçeğin özgün formunda toplam 12 madde bulunmakta olup, 5 maddeden oluşan Öfkeyi Yıkıcı İfade Etme ve 7 maddeden oluşan Öfkeyle Olumlu Baş etme alt boyutları vardır. Ölçek bütün olarak kullanılmasının yanında iki ayrı alt boyutu da bağımsız olarak kullanılabilmektedir. Ölçme aracı Türkiye kültürüne Canbuldu (2006) tarafından uyarlanmıştır. Kültüre uyarlama sürecinde geçerlilik çalışmasında Durumluluk-Süreklilik Öfke ölçeği kullanılmıș olup aralarındaki toplam korelasyon katsayısı .58 olarak belirlenmiștir. Geçerlik için yapılan diğer bir çalışmasında "Öfkeyle Olumlu Baş etme" alt ölçeği için faktör yükleri ise .43 ile .73 arasında değişmektedir. Ölçeğin her iki alt boyutu arasındaki korelasyon -.50 olarak elde edilmiştir. Güvenirlik çalışmaları sonucunda ise ölçeğin tümü için Cronbach alpha iç tutarlılık kat sayıs1 .85, Öfkeyle Olumlu Baş etme alt ölçeği için .73olarak elde edilmiştir. Test tekrar test güvenirlik çalışmasında ise Öfkeyle Olumlu Baş etme alt ölçeği için .62'lik bir korelasyon elde 
edilmiştir. Bu çalışmada ölçeğin Öfke İle Olumlu Baş etme alt ölçeği için güvenirlik katsayısı. 70 olarak bulunmuştur.

Arkadaş Bağlllık Ölçeği (AB̈̈): Armsden ve Greenberg (1987) tarafindan özgün formu geliştirilen ölçeği, Türkiye kültürüne Hortaçsu, Oral ve Yasak-Gültekin (1991) uyarlamıştır. 1 (Her zaman) ile 5 (Hiçbir zaman) arasında puanlanan ölçme aracı, 25 maddeden oluşan Likert tipi ölçektir. Ölçeğin en yüksek puanı 125 , en düşük puanı ise 25tir. Bu uyarlama çalışmasında ölçeğin özgün formundaki gibi "güven", "iletişim" ve "yabanc1laşma" şeklinde üç alt boyuttan oluşan bir yapıya sahip olduğu görülmüştür. Güvenirlik için yapılan çalışmada ise alt boyutların her biri için sırasıyla Cronbach alpha iç tutarlılık katsayıları $.90, .68$ ve.73 olarak bulunmuştur. Aynı ölçeğin Löker (1999), tarafindan yapılan başka bir uyarlama çalışmasında ise tek faktörlü bir yapı elde edilmiştir. Tek faktörlü bu yapıda maddeler arası korelasyon .51 ve .75 arasındadır. İkinci kez yapılan bu uyarlama çalışmasında ise güvenirlik iç tutarlılığı ise .86 olarak hesaplanmıştır. Ölçekten alınan puan artıkça arkadaş bağlılığı da artmaktadır. Bu çalışmada ABÖ’nün iç tutarlık katsayısı .87 olarak elde edilmiştir.

Akran Baskısı Ölçeği (ABÖ): Ölçek Kıran (2009) tarafından geliştirilmiştir. İki alt boyuttan oluşan ölçekte 19 madde doğrudan, 15 madde dolaylı; toplamda 34 madde akran baskıs1 düzeyini ölçmektedir. Ölçek 5'li Likert tipi olarak tasarlanmıştır. Faktör analizi yoluyla yapılan geçerlik çalışmasında doğrudan akran baskısı faktör yükleri .308 - .747 ve dolaylı akran baskısı boyutu faktör yükleri ise .366 - . 597 arasında değişmekte ve ölçek varyansın \% 40.527'sini açıklamaktadır. Ölçeğin doğrudan akran baskısı alt boyutunun cronbach alpha güvenirlik katsayıs1 .89, dolaylı yoldan akran baskıs1 cronbach alpha güvenirlik katsayıs1 ise .82'dir. Ölçeğin toplam maddelerinin cronbach alpha güvenirlik katsayısı ise .90 olarak bulunmuştur. Doğrudan bask1 alt boyutu ile ölçeğin toplam puanları arasındaki korelasyon katsayıs1 .94 $(\mathrm{p}<.01)$; dolaylı baskı alt boyutu ile ölçeğin toplam puanları arasındaki korelasyon katsayısı ise $.74(\mathrm{p}<.01)$ 'dür. Her iki alt boyut arasındaki korelasyon katsayısı ise .46 olarak bulunmuştur (Kıran, 2003). Gündüz ve Çelikkaleli (2009) yaptıkları bir çalı̧̧mada ise ölçeğin güvenirliğine dair iç tutarlılık katsayısı .96 olarak bulunmuştur. Bu çalışmada iç tutarlık katsayısı ise .80 olarak hesaplanmiştır.

Kişisel Bilgi Formu: Araştırmacılar tarafından hazırlanan demografi veri formunda araştırmaya katılan öğrencilerin yaş, cinsiyet ve algılanan sosyal destek kategorisi bulunmaktadır. Algılanan sosyal destek kaynakları ise $(1=$ Aile, $2=$ Arkadaş, $3=$ Her ikisi $=$ Aile ve arkadaş, $4=$ Hiç kimseden) olarak belirlenmiştir.

\section{Verilerin analizi}

Araştırmada verilerin analizi için SPSS 23programı kullanılmıştır. Ergenlerin öfkeleriyle olumlu baş etme biçimlerinin, akran baskısı, arkadaş bağl1lı̆ 1 , algılanan sosyal destek ve cinsiyet düzeyleri açısından incelenmesi için öncelikle kategorik değişken olduğu için algılanan sosyal destek ve cinsiyet verileri çıkarılarak korelasyon analizi yapılmıştır. Sonraki aşamada bu iki kategorik değişkenin de yer aldığı regresyon analizi yapılmıştır.

Analizlere geçmeden önce verilerin normal dağılım gösterip göstermediğine bakılmıştır. $\mathrm{Bu}$ çerçevede verilerin dağılımına ilişkin basıklık ve çarpıklık (Skewness ve Kurtosis) katsayıları incelenmiştir. Öfkeyi olumlu ifade etme biçimi için elde edilen katsayılar .921- .543; akran baskısı için 1.676-1.980 ve arkadaş bağl1lı̆̆ için -.290- -.396 olarak elde edilmiştir. Bu bulgular verilerin normal dağ 1 lım gösterdiğine işaret etmektedir. Ayrıca, veriler arasında çoklu bağlantı sorununun olup olmadığına bakıldığında ise Tollerans değeri WIF değerleri de değişkenler arasındaki çoklu bağlantı sorunu olmadığını göstermektedir (.998-1.167).

Araştırmanın bağımlı değişkeni olan öfkeyi olumlu ifade etme biçimlerinin cinsiyete göre farklılaşıp farklılaşmadığını belirlemek için t-Testi yapılmıştır. Yine öfkeyi olumlu ifade etmenin, algılanan sosyal desteğe göre farklılaşıp farklılaşmadığını ortaya koymak için betimsel ve varyans analizi yapılmıştır. 


\section{Bulgular}

Bu bölümde araştırmanın alt problemlerine yönelik bulgular sunulmuştur.

Ergenlerin okulda öfkeleriyle olumlu baş etme biçimleri, akran baskısı ve arkadaş bağl11ıklarına ilişkin betimsel bulgular ve korelasyon katsayıları Tablo 1'de verilmiştir.

Tablo 1.

Ergenlerin Okulda Öfkeleriyle Olumlu Baş Etme Biçimleri, Akran

Baskısı ve Arkadaş Bağlılığı Arasındaki İlişkiler

\begin{tabular}{lccccc}
\hline Değişkenler & $\overline{\mathrm{X}}$ & $\mathrm{Sd}$. & 1 & 2 & 3 \\
\hline 1-Öfkeyi Olumlu Başetme & 8.63 & 2.81 & 1 & & \\
2-Akran Baskıs1 & 48.62 & 18.58 & $.43^{* *}$ & 1 & \\
3-Arkadaş Bağl1lığ & 94.25 & 15.04 & $.21^{* *}$ & $-.23^{* *}$ & 1 \\
\hline $\mathrm{N}=544,{ }^{* *} \mathrm{p}<.01$ & & & & &
\end{tabular}

Tablo 1'de değişkenler arasındaki ilişkiler verilmiştir. Buna göre, okulda öfkeyle olumlu baş etme biçimleri puanları ile akran baskısı $(r=.43, \mathrm{p}<.01)$ ve arkadaş bağ 111 ğ pozitif yönde anlamlı ilişkiler elde edilmiştir $(r=.21, p<.01)$. Diğer taraftan, akran baskısı ile arkadaş bağl1lığı arasında negatif yönde anlamlı bir ilişki bulunmaktadır $(r=-.23, p<.01)$

Ergenlerin akran baskılarının, algılanan sosyal destek kaynaklarının, arkadaş bağl1lıklarının ve cinsiyetlerinin okulda öfkeyle olumlu baş etme biçimini yordamasına ilişkin bulgular Tablo 2'de verilmiştir.

Tablo 2.

Ergenlerin Akran Baskılarının, Algılanan Sosyal Destek Kaynaklarının, Arkadaş Bağlılıklarının ve Cinsiyetlerinin Okulda Öfkeyle Olumlu Baş Etme Biçimini Yordamasına İlişkin Bulgular

\begin{tabular}{llllllll}
\hline Değişkenler & $\mathrm{R}$ & $\Delta \mathrm{R}^{2}$ & $\mathrm{~B}$ & $\mathrm{~S} . \mathrm{H}$. & $\beta$ & $\mathrm{t}$ & $\mathrm{p}$ \\
\hline Sabit & ----- & ---- & 5.627 & .956 & ----- & 5.889 & .000 \\
Akran Bask1s1 & .430 & .185 & .056 & .006 & .368 & 9.310 & .000 \\
Algılanan Sosyal & .464 & .215 & .495 & .108 & .175 & 4.588 & .000 \\
Destek & .479 & .225 & -.018 & .008 & -.096 & -2.357 & .019 \\
Arkadaş Bağl1lı̆̆1 & .486 & .231 & .520 & .233 & .091 & & \\
Cinsiyet & & & &
\end{tabular}

$\mathrm{R}=0.486 . \mathrm{R} 2=0.231 ; \mathrm{F}=41.676, \mathrm{p}<.000$

Tablo 2 incelendiğinde, ergenlerinin Okulda Öfkeleriyle Olumlu Baş etme puanlarına ilişkin varyansını açıklamada dört değişkenin de anlamlı düzeyde bağımlı değişkeni yordadıkları görülmektedir. Analizin ilk aşamasında "akran baskısı" puanlarının toplam varyansın \%18,5'ini; ikinci aşamada "algılanan sosyal destek kaynakları" puanlarının \%3.0'ünü, üçüncü aşamada "arkadaş bağlılığı" puanlarının \%1.0'ını ve "cinsiyetin" \%0.6'sını açıkladığ1 görülmektedir. Dört değişken birlikte ergenlerin öfkeyi olumlu ifade etme puanlarına ilişkin varyansın toplam \%23'ünü açıklamaktadırlar [F=41.676, $\mathrm{p}<.000]$.

Ergenlerin cinsiyetlerine göre okulda öfkeyle olumlu baş etme biçimlerinin farklılaşmasına ilişkin bulgular Tablo 3 'te verilmiştir.

Tablo 3incelendiğinde ergenlerde öfkeyle olumlu baş etme puanlarının anlamlı bir biçimde farklılaştığ 1 görülmektedir( $\mathrm{t}=-5.296, \mathrm{p}<.01)$. Diğer bir ifadeyle, erkek ergenlerin kız ergenlere göre okulda öfkeleriyle daha olumlu baş edebildikleri söylenebilir. 
Tablo 3.

Ergenlerin Cinsiyetlerine Göre Okulda Öfkeyi Olumlu İfade Etme Biçimlerine İlişkin Betimsel Bulgular ve T-Testi Sonuçları

\begin{tabular}{|c|c|c|c|c|c|c|}
\hline Değişken & Cinsiyet & $\mathrm{N}$ & $\bar{X}$ & Ss & $\mathrm{t}$ & $\mathrm{p}$ \\
\hline & $\mathrm{K}_{1 \mathrm{Z}}$ & 326 & 8.12 & 2.53 & -5.296 & .000 \\
\hline Başetme & Erkek & 218 & 9.39 & 3.02 & & \\
\hline
\end{tabular}

Ergenlerin algılanan sosyal destek kaynaklarına göre okulda öfkeyle olumlu baş etme puanlarına ilişkin betimsel bulgular Tablo 4'te verilmiştir.

Tablo 4.

Ergenlerin Algıladıkları Sosyal Destek Kaynaklarına Göre Okulda Öfkeyle Olumlu Baş Etme Puanlarına İlişkin Betimsel Bulgular

\begin{tabular}{|c|c|c|c|c|c|c|}
\hline Değişken & $\begin{array}{l}\text { Algılanan Sosyal } \\
\text { Destek Kaynağ } 1\end{array}$ & $\mathrm{~N}$ & $\bar{X}$ & Ss & Min. & Max. \\
\hline \multirow{4}{*}{$\begin{array}{l}\text { Öfkeyi Olumlu İfade } \\
\text { Etme }\end{array}$} & 1-Aile & 120 & 7.60 & 2.52 & 5.00 & 17.00 \\
\hline & 2-Arkadaş & 87 & 8.88 & 2.73 & 5.00 & 17.00 \\
\hline & 3-Her İkisi (Aile+Arkadaş) & 257 & 8.61 & 2.72 & 5.00 & 18.00 \\
\hline & 4-Hiç Kimseden & 80 & 9.96 & 3.02 & 5.00 & 17.00 \\
\hline
\end{tabular}

Tablo 4'e göre, ergenlerden algıladıkları sosyal destek kaynağ " “ailesi” olanların okulda öfkeyle olumlu baş etme ortalaması 7.60 (2.52), sosyal desteği "arkadaşı" olanların ortalaması 8.88 (2.73), sosyal desteği "hem aile hem arkadaş" olanların ortalaması 8.61 (2.72) ve "hiç kimseden" sosyal destek görmediğini ifade edenlerin ortalaması $9.96(3,02)$ olarak elde edilmiştir.

Algılanan sosyal destek kaynaklarına göre okulda öfkeyle olumlu baş etme biçimlerine ilişkin puanları açısından ortaya çıkan farklılaşmanın anlamlı olup olmadığına yönelik bulgular Tablo 5'te verilmiştir.

Tablo 5.

Algılanan Sosyal Destek Kaynaklarına Göre Okulda Öfkeyle Olumlu Baş Etme Biçiminin Farklılaşmasına İlişkin Varyans Analizi Sonuçları

\begin{tabular}{llccccc}
\hline Değişken & $\begin{array}{c}\text { Varyansın } \\
\text { Kaynağ }\end{array}$ & $\begin{array}{c}\text { Kareler } \\
\text { Toplamı }\end{array}$ & sd & $\begin{array}{c}\text { Ortalama } \\
\text { Kareler }\end{array}$ & F & $\begin{array}{c}\text { Farkın } \\
\text { Kaynağ } \\
\text { (LSD) }\end{array}$ \\
\hline Öfkeyle & Olumlu Grup. Aras1 & 273.051 & 3 & 91.017 & & $3>1$ \\
Başetme & Olumlu Grup İçi & 4021.419 & 540 & 7.447 & $12.222 *$ & $4>1,23$ \\
İfade Etme Biçimi & Toplam & 4294.471 & 543 & & & \\
\hline
\end{tabular}

Tablo 5 incelendiğinde de görüleceği üzere algılanan sosyal destek kaynaklarına göre ergenlerin okulda öfkeleriyle olumlu baş etme puanlarının anlamlı bir biçimde farklılaştığ görülmektedir $\left[\mathrm{F}_{(3-540)}=12.222, \mathrm{p}<.01\right]$. Gruplar arasında ortaya çıkan farkın kaynağ incelendiğinde hem ailesinden hem de arkadaşlarından sosyal destek algılayan ergenlerin okulda öfkeleriyle olumlu baş etme biçimi puanlarının ortalaması sosyal desteği sadece ailesinden algılayanlardan daha yüksektir. Ayrıca, "hiç kimseden" sosyal destek algılamayan ergenlerin okulda öfkeleriyle olumlu baş etme biçimi puanlarının ortalamasının "aileden", "arkadaşlardan" ve "hem aileden hem de arkadaşlarından" sosyal destek algılayanların ortalamasından daha yüksektir.

\section{Tartıșma, Sonuç ve Öneriler}

$\mathrm{Bu}$ bölümde araştırma bulguları çerçevesinde elde edilen bulgular tartışılmış, yorumlanmış ve önerilerde bulunulmuştur. 
Feindler ve Engel (2011) öfkenin ifade edilme biçiminin birçok sosyal ilișki örüntüsü üzerinde etkili olduğunu belirtmişlerdir. Araştırmada öfkeyle olumlu baş etme biçiminin ergenin sosyal ilişkilerini belirleyen akran baskısı, arkadaş bağlılığı, algıladıkları sosyal destek ve cinsiyetlerine göre ne düzeyde yordandığı ve anlamlı farklılıklar olup olmadığı belirlenmek istenmiştir.

Ergenlerin öfkeleriyle olumlu baş etme biçimleriyle akran baskısı arasındaki ilişkiyi ortaya koyan çok fazla çalışmaya ulaşılamamıştır. Sadece Hernawati, Rahayu ve Soejowinoto (2015) yanlış öfke ifade düzeyinin, akran baskısıyla arasında pozitif yönde bir ilişki bulmuştur. $\mathrm{Bu}$ sonuca paralel bir şekilde araştırmamızda ise ergenlerin öfkesini olumlu ifade etmeleriyle akran baskısı arasında kabul edilebilir düzeyde bir ilişki bulunmuş ve akran baskısı öfkeyi olumlu iade etmeyi \% 18.5 düzeyinde yordamıştır. Diğer bir deyişle ergenlerin öfkelerini ifade etme biçimlerinde akran baskısının etkisi önemsenecek kadar bir paya sahiptir. Ergenlerin yaşam süreçlerinde arkadaşlarıyla kurmuş olduğu ilişkiler belirleyici bir role sahiptir. Ergenler bazen bir gruba kabul edilmek için akranları gibi davranabilir veya davranışlarında onlardan etkilenebilirler (Tarshis, 2009). Bu açıdan bakıldığında akran baskısının öfkeyi olumlu ifade etmede açıklayıcı bir rolünün olduğu görülmektedir. Tarshis (2009), olumsuz yöndeki akran baskısının kızgınlık, korku, öfke gibi olumsuz duygulara sahip olmanın yanında, olumlu yöndeki akran baskısının bireyi duygusal açıdan daha iyi hissettirebileceğinden bahsetmiştir. Ayrıca gruba kabul edilmeye yönelik aynı giysileri giyme, aynı şekil saç kestirme, aynı şekil davranışlarda bulunma akran baskısının bir diğer yönü olmakla birlikte, bu yöndeki davranışlarda bulunma ergenin akran grubuna daha kolay kabul edilmesini sağlamaktadır. $\mathrm{Bu}$ durum da bireyin akran ilişkileri açısından olumsuz duygular yaşamasının önüne geçmektedir (De Guzman, 2009). Akran baskısı, bazen bireyin bir gruba dâhil olmasının yanı sıra, bireye sorumluluk alma, görevlerini yerine getirme, mücadeleci olma gibi olumlu özellikler de kazandırabilmektedir (Griskevicius, Cialdini ve Goldstein, 2009). Diğer taraftan düşük benlik saygısına sahip olan bazı ergenler, diğerleri tarafından baskı ve etki altına alınmayı bir kabul olarak görebilirler. Özellikle statü açısından kendisinden daha yüksek düzeydeki bir arkadaşının etkisiyle karşılaşan bir ergen bu durumdan dolayı kendisini daha iyi hissedebilmektedir (Santrock, 2014).

$\mathrm{Bu}$ yönlerden bakıldığında bulgularımızda akran baskısının öfkeyi olumlu ifade etmedeki etkisi gruba kabul edilmeye yönelik sergilenen davranışların ergenin kendini psikolojik açıdan daha iyi hissetmesi olabileceği ve bunun öfkenin olumlu ifade edilmesine yansıdığı düşünülmektedir. Ayrıca akran baskısının sadece olumsuz yönünün değil, olumlu yöndeki akran etkileşimlerinin de ergenin duygularında, dolayısıyla öfkesiyle daha olumlu bir biçimde baş etmesine katkısının olduğu öne sürülebilir.

Arkadaş bağlığı, öfkeyle olumlu başa çıkma açısından hem olumlu hem de olumsuz şekilde etkiye yol açtığı düşünülebilir. Çalışmamızda arkadaş bağlığı ile öfkeyle olumlu başa çıkma arasında orta düzeyde korelasyonel bir ilişki olmasına rağmen, arkadaş bağlı̆̆ının öfkeyle olumlu başa çıkmayı açıklama düzeyi düşük çıkmıştır. Diğer bir deyişle arkadaşa olan bağlılık arttıkça öfkeyle olumlu başa çıkma düzeyi de artmaktadır. Fakat bu ilişki düzeyi anlamlı bir şekilde yüksek değildir. Bu bulgumuza benzer bir şekilde Saçar (2007) ergenler üzerindeki çalışmasında öfke puanları ile arkadaş bağlığı arasında anlamlı bir fark bulamaz iken öfke düzeyi düşük olanların, yüksek olanlara göre arkadaşlarına daha bağlı olduğu sonucunu ortaya koymuştur. Kanoğlu (2008) lise öğrencilerinin arkadaşlarıyla ilişkilerinin kısıtlanmasının öfkelerini olumsuz şekilde ifade etmesine yol açtı̆̆ sonucuna ulaşmıştır. Ayrıca Avcı ve Güçray (2013) akran ilişkilerinin niteliğinin, öfkeyi olumsuz ifade etmenin bir yolu olan şiddete yönelik davranışların yordayıcısı oluğunu belirtmişlerdir. Yine Avcı ve Çelikkaleli (2016) bir şekilde akranlarının etkisi altında kalanların -özellikle akran zorbalığı- öfkeye yönelik duygularını şiddete başvurarak gösterdiklerini belirtmişlerdir. Demir ve Kaya (2008), yapmış oldukları deneysel çalışmada ergenlerin arkadaşlığa yönelik bilgilerini geliştirdikleri ve arkadaşlarıyla daha sağlıklı ilişkiler kurduklarında zaman daha yapıcı davrandıklarını ortaya koymuşlardır. Araştırmanın bulguları ve diğer çalışmalar ele alındığında ergenlik dönemi sürecinde en önemli çevre, birey için arkadaşlarıdır. Ergenlerin arkadaşlarıyla kurduğu ilişkiler 
genelde onlara özel olup, ilişkinin niteliği ise hayati role sahiptir (Santrock, 2014). Özellikle ergenlerin duygularını daha olumlu ifade edebilmeleri kurdukları ilişkilerle ilişkilidir. Kurduğu güçlü ilişkinin farkında olan ergenler, duygularını düzenlemede daha başarılıdırlar (Santrock, 2014). Araştırma sonuçlarımıza göre ergenlerin arkadaşlarıyla ilişkilerinin niteliği ve bağlılığı arttıkça duygularını düzenlemede ve dolayısıyla öfkeleriyle olumlu bir biçimde başa çıkmada daha başarılı oldukları söylenebilir.

Ergenlerin öfkeleriyle olumlu başa çıkma biçimlerini, araştırma bulgularına göre algıladıkları sosyal destek kaynakları düşük düzeyde yordamaktadır. Hiç kimseden sosyal destek algisı olmayan ergenler öfkelerini, aileden ve arkadaşlardan sosyal desteği algılayanlara göre daha olumlu ifade edebilmektedirler. Çivitçi (2011), yapmış olduğu çalışmada aile, arkadaş, öğretmenden alınan sosyal destek anlamında sadece öğretmenlerden sosyal destek alanların öfkelerini daha olumlu ifade ettiklerini belirtmiştir. Araştırmamızda algılanan sosyal destek kategorisinde aile ve arkadaştan algılanan sosyal destek seçenekleri göz önüne alındığında bahsedilen çalışma, araştırma sonuçlarımızı destekleyici niteliktedir. Araştırma sonuçlarımızla uyuşmayan bir şekilde Smith ve Thomas, (2000) ailesinden sosyal destek alamayan öğrencilerin öfkesini olumsuz ifade ettiklerini belirtmişlerdir. Ergenlik döneminde arkadaşlara dair beklentiler yüksek olmakla birlikte onları en yakın kişi olarak görürler (Bee ve Boyd, 2009). Araştırma sonuçlarına göre ergenlerin arkadaşlarından sosyal destek alamamasında bu dönem içerisinde ergenlerin arkadaş çevresine karşı aşırı duygusal beklentilerinin olması sonucunda duygusal başta olmak üzere diğer ihtiyaçlarının karşılanamayacağını ve kurulan arkadaşlıkların kalıcı olmayacaklarını anlamaları (Bee ve Boyd, 2009) etkili olabilir. Ergenlerin içinde bulundukları gelişim süreci nedeniyle aile ile çatışmaları yeni bir kimlik bulma çabasının etkisiyle artabilir. Özellikle ergenliğin başlarında ebeveyn müdahaleci ise bu çatışmanın şiddeti ve düzeyi üst noktaya çıkar (Santrock, 2014). Ayrıca ergenler genellikle zamanlarını aileden uzak ve dışarıda arkadaşlarıyla geçirmek isterler ve ailenin bu konudaki isteklerinden hoşlanamazlar (Hagell, Peck ve Zarrett, 2012). Bulgulara göre ergenlerin, aileden gelen sosyal desteği bu çatışma nedeniyle sosyal destek yerine bir müdahale olarak algılayabildikleri ve ailesiyle aralarına koydukları mesafe nedeniyle öfkeleriyle olumlu bir biçimde başa çıktıkları düşünülmektedir.

Öfkeyle olumlu başa çıkma puanlarında cinsiyet değişkenine göre erkeklerin lehine bir farklılık olsa da bunun önemli bir düzeyde olmadığ anlaşılmaktadır. Bulgumuzu benzer bir şekilde birçok çalışma desteklemektedir. Evren ve diğerleri (2015) agresif ve öfke temelli davranışlarda ergen kızların lehine fark bulmuşlardır. Yine cinsiyet değişkenine göre öfkenin olumlu ifade edilmesi sonucumuza göre Ghanizadeh, (2008) İran'da yapmış olduğu çalışmada öfkenin olumsuz şekilde ifade edilmesinde kızların lehine bir fark bulsa da bunu anlamlı olarak kabul etmemiştir. Boman (2003) ise yine öfkenin davranışsal olarak ifade edilmesinde kızların daha başarısız olduğu sonucuna ulaşmıştır. BakerErdur ve diğerleri (2009), öfkenin içe yönelik yaşanmasında kız ergenlerin, dişa yönelik yaşanmasında ise erkek ergenlerin lehine bir farklılık bulmuşlardır. Bu çalışmaya göre hem erkekler hem de kızlar öfkelerini birbirlerine göre anlamlı bir șekilde olumsuz olarak yansıtmaktadır. Bu araştırma bulgusu ve diğer araştırma bulguları gösteriyor ki; öfkeyle olumlu veya olumsuz başa çıkmada cinsiyet değişkeninin yüksek düzeyde belirleyici olmadığ söylenebilir. Ergenlik dönemine ait kaynaklar incelendiğinde ise öfkeyle olumsuz başa çıkmada veya şiddete yönelik davranışlarda cinsiyet değişkenine çok değinilmediği görülebilir.

Araştırma sonuçlarıma göre öfkeyle olumlu başa çıkmada akran baskısının arasında pozitif yönde bir ilişki olduğu, bağımsız değişkenlerden ise en çok akran baskısının öfkeyle olumlu başa çıkmayı yordadığı sonucuna ulaşılmıştır. Arkadaş bağlığı ile öfkeyle olumlu başa çıkma arasında orta düzeyde ilişki bulunmuş ve yordama düzeyi düşük bulunmuştur. Bulgulardan hiç kimseden sosyal destek almadığını belirten ergenlerin, sosyal desteği aile ve arkadaştan algılayan ergenlere göre öfkeleriyle olumlu başa çıkmada ve genel olarak algılanan sosyal desteğin, öfkeyle olumlu başa çıkmayı çok düşük düzeyde, ancak anlamlı bir biçimde, yordadığı sonucu elde edilmiştir. Cinsiyet değişkenine göre öfkeyle olumlu başa çıkma puanları 
açısından bir fark bulunmuş olsa da bu farkın anlamlı olmadığı ve öfkeyle olumlu başa çıkmayı en düşük düzeyde yordadığ 1 sonucuna ulaşılmıştır.

Birçok araştırmada olduğu gibi gerçekleştirilen bu araştırmanın da bazı sınırlıkları bulunmaktadır. Öncelikle öfkenin olumlu ifade edilmesi Çok Boyutlu Okul Öfke İfade Biçimleri Ölçeği'nin bir alt ölçeğiyle belirlenmesi bu araştırmanın bağımlı değişkeni olan okulda öfkeyle olumlu başa çıkma açısından bir sınırlılık oluşturmuştur. Ayrıca verilerin Türkiye'nin tüm bölgelerinden elde edilmemiş olması bulguların genellenebilirliğine yönelik bir sınırlılık oluşturmaktadır. Son olarak da, ergenlerin okulda öfkeleriyle olumlu başa çıkmalarını etkileyebilecek birçok faktör olmasına rağmen bu çalışmada arkadaş bağlılığı, akran baskısı, algılanan sosyal destek ve cinsiyet değişkenlerinin ele alınmış olması da bir sınırlılık olarak değerlendirilebilir.

Elde edilen bulgular, yorumlar ve sınırlılıklar çerçevesinde şu önerilerde bulunulabilir. Ergenlerin öfkeleriyle olumlu başa çıkmalarını etkileyebilecek kişilik özellikleri, sosyal ilgileri, stresle başa çıkma tarzları, toplumsal cinsiyet rolleri değişkenlerinin rolüne yönelik daha geniş örneklemli çalışmalar yapılabilir. Özellikle ergenlik döneminde öfkeyi etkileyen ebeveyn tutumlarına bağlı olarak ebeveyn-ergen ilişkileri geliştirmeye yönelik psiko-eğitim programlarının geliştirilmesi faydalı olacağı düşünülmektedir. Ergenlerin öfkelerinin dönemsel bir özellik olduğu düşünüldüğünde, ergenlik dönemine yönelik öğrenciler için hem önleyici hem geliştirici okul psikolojik danışma ve rehberlik programlarının geliştirilmesi ve uygulanmasının katkı sağlayacağı düşünülmektedir.

\section{Kaynaklar}

Armsden, G. C. ve Greenberg, M. T. (1987). The inventory of parent and peer attachment: Individual differences and their relationships to psychological well-being in adolescence. Journal of Youth and Adolescence, 16(5). 427-454. doi: 10.1007/ BF02202939

Avci, R. ve Çelikkaleli, Ö. (2016). Peer victimization, trait anger and alienation as predictors of violence tendency in adolescents. Journal of Educational Sciences Research, 6(2), 151167.10.12973/jesr

Avci, R. ve Gucray, S. S. (2013). The relationships among interparental conflict, peer, media effects and the violence behaviour of adolescents: The mediator role of attitudes towards violence. Educational Sciences: Theory and Practice, 13(4), 2005-2015.

Boman, P. (2003). Gender differences in school anger, International Education Journal, 4(2), 71-77.

Blakemore, S. J. ve Mills, K. L. (2014). Is adolescence a sensitive period for sociocultural processing? Annual Review of Psychology, 65(1), 187-207. doi: 10.1146/annurev-psych010213-115202

Bee, H. ve Boyd D. (2009). The developing child. Çocuk gelişim psikolojisi. O. Gündüz (Çev.). İstanbul, Kaknüs Yayınları.

Canbuldu, S. (2006). Çok boyutlu okul öfke envanterinin Türkçe'ye uyarlama çalışması (Yayımlanmamış yüksek lisans tezi). Mersin Üniversitesi Sosyal Bilimler Enstitüsü: Mersin.

Chappell, N. L. ve Funk, L. M. (2011). Social support, caregiving, and aging. Canadian Journal on Aging, 30(3). doi:10.1017/S0714980811000316

Civitçi, N. (2011). School alienation and perceived social support as predictors of school anger in high school students, Illkögretim Online, 10(3), 861-871.

Cobb, S. (1976). Social support as a moderator of life stress. Psychosomatic Medicine, 38(5), 300-314. http://dx.doi.org/10.1097/00006842-197609000-00003

Cohen, S., Gottlieb, B. H. ve Underwood, L. G. (2000). Social relationships and health. S. Cohen L. G. Underwood, B. H.Gottlieb (Yay.haz.). Social support measurement and intervention: A guide for health and social scientists. New York, NY: Oxford University Press. 
Cohen, S. ve Wills, T. A. (1985). Stress, social support, and the buffering hypothesis. Psychological bulletin, 98, 310-357.

Coyne, J. C. ve Downey, G. (1991) Social factors and psychopathology: stress, social support, and coping processes. Annual Review Psychology, 42, 401-425. https://doi.org/10.1146/ annurev.ps.42.020191.002153

De Guzman, M. R. T (2009). Peer pressure: an overview. L. Savage (Yay.haz.). Peer Pressure. 11-20. Detroit: Gale and Greenhaven Press.

Demir, S. ve Kaya, A. (2008). The effect of group guidance program on the social acceptance levels and sociometric status of adolescents, Elementary Education Online, 7(1), 127140.

Eisenberg, N., Fabes, R. A., Murphy, B., Maszk, R, Smith, M. ve Karbon, M. (1995). The role of emotionality and regulation in children's social functioning: A longitudinal study. Child Development, 66, 1360-1384. https://doi.org/10.1111/j.1467-8624.1995.tb00940.x

Elliot, C. H. ve Smith, L. L. (2017). Öfke kontrolü (Kişisel gelişim). S. Dilan (Çev.). Üçüncü, Ankara, Nobel Akademi.

Erdur-Baker, Ö., Özgülük, S. B, Turan, N. ve Danış1k, N. D (2009). Ergenlerde görülen psikolojik belirtilerin yordayıcıları olarak ruminasyon ve öfke/ öfke ifade tarzları. Türk Psikolojik Danışma ve Rehberlik Dergisi, 4(32), 43-53.

Evren, C., Bozkurt, M., Çiftçi Demirci, A., Evren, B., Can, Y. ve Umut, G. (2015). Gender differences according to psychological and behavioral variables among 10th grade students in Istanbul. Anadolu Psikiyatri Dergisi. 16. 77-84

Feindler, E. L. ve Engel, C. E. (2011). Assessment and intervention for adolescents with anger and agression diffuculties in school settings. Psychology in the Schools, 48(3), 243-253. https://doi.org/10.1002/pits.20550

Fryxell, D. ve Smith, D. C, (2000). Personal, social and family characteristics of angry students. Professional School Counseling, 4(2), 86-94.

Ghanizadeh, A. (2008). Gender difference of school anger dimensions and its prediction for suicidal behavior in adolescents. International Journal of Clinical and Health Psychology, 8(2), 525-535.

Goel, R. ve Malik, A. (2017). Risk taking and peer pressure in adolescents: A correlational study. Indian Journal of Health and Well-being, 8(12), 1528-1532.

Gottlieb, B. H. ve Bergen, A. E. (2010). Social support concepts and measures. Journal of Psychosomatic Research, 69(5), doi:10.1016

Griskevicius, V., Cialdini, R. B ve Goldstein, N. J. (2009). Peer pressure can be used positively to change behavior. L. Savage (Yay. haz.). Peer Pressure, 48-58. Detroit: Gale and Greenhaven Press.

Gündüz, B. ve Çelikkaleli, Ö. (2009). Ergen saldırganlığında akademik yetkinlik inancı, akran baskısı ve sürekli kaygının rolü. İnönü Üniversitesi Eğitim Fakültesi Dergisi, 10(2), 1938.

Hagell, A., Peck, S. C. ve Zarrett, N. (2014). Trends in parenting: can they help explain time trends in problem behaviour? Hagel, A. (Yay. haz.). Changing adolescence; Social trends and mental health içinde (ss. 75-93). Bristol: The Policy Press

Hernawati, L., Rahayu, E. ve Soejowinoto, P. (2015). The predictors of indonesian senior high school students' anger at school, Journal of Education and Practice, 6(23), 108-119. Eric Number: EJ1079035

Hortaçsu, N., Oral, A. ve Yasak-Gültekin, Y. (1991). Factors affecting relationships of Turkish adolescents with parents and same-sexfriends. The Journal of Social Psychology, 131(3), 413-426.

Kanoğlu, E. (2008). Lise ögrencilerinin öfke düzeyleri ve öfke ifadelerinin incelenmesi (Yayımlanmamış yüksek lisans tezi). Haliç Üniversitesi, İstanbul.

Karasar, N. (2014). Bilimsel araştırma yöntemi (26.bask1). Ankara: Nobel Yayınc1lık 
Kıran, B. (2002). Akran baskısı düzeyi farklı olan ögrencilerin risk alma, sigara içme davranışı ve okul başarılarının incelenmesi (Yayınlanmamış doktora tezi). Gazi Üniversitesi. Ankara.

Löker, Ö. (1999). Differential Effects of Parentand Peer Attachment on Social and Emotional Loneliness Among Adolescents (Yayımlanmamıs yüksek lisans tezi). Ortadoğu Teknik Üniversitesi, Sosyal Bilimler Enstitüsü.

Maxwell, K.A (2002). Friends: The role of peer influence across adolescent risk behaviors. Journal of Youth and Adolescence, 31(4), 267-277. http://dx.doi.org/10.1023/A:1015493316865

Philips-Hershey, E. ve Kanagy, B. (1996). Teaching students to manage personal anger constructively. Elementary School Guidance \& Counseling, 30(3), 229-234.

Saçar, A. (2007). Illkögretim sekizinci sınıf ögrencilerinin öfke tepkisiyle arkadaş bă̆lllı̆̆ının incelenmesi (Yayımlanmamış yüksek lisans tezi). Çukurova Üniversitesi, Adana

Santor, D. A., Messervey, A. D. ve Kusumakar, V. (2000). Measuring peer pressure, popularity, and conformity in adolescent boys and girls: predicting school performance, sexual attitudes, and substance abuse. Journal of Youth and Adolescence, 29(2), 163-182.

Santrock, J. W. (2014). Adolescence (Fifteenth edition). Newyork: McGraw-Hill Education.

Schaefer C., Coyne, J. C. ve Lazarus R. S. (1981) The health-related functions of social support, Journal of Behavioral Medicine, 4(4), 381-406.

Shilts, L. (1991). The relationship of early adolescent substance use to extracurricular activities, peer influence, and personal attitudes, Adolescence, 26(103), 613-617.

Smith, H. ve Thomas, S. P. (2000). Violent and nonviolent girls: contrasting perceptions of anger experiences, school, and relationships. Issues in Mental Health Nursing, 21, 547575.

Smith, D. C. ve Furlong, M. J. (1994). Correlates of anger, hostility, and aggression in children and adolescents. M. J. Furlong ve D. C. Smith (Yay. haz.). Anger, hostility, and aggression: Assessment, prevention, and intervention strategies for youth. 15-38. New York: John Wiley.

Smith, D. C., Furlong, M. J. ve Boman, P. (2006). Assessinganger and hostility in school settings. R. Shane, Jimerson ve Michael J. Furlong (Yay. haz.) Handbook of School Violence and School Safety: From Research to Practice, 135-146

Smith, D. C., Furlong, M. E., Bates, M. ve Laughlin, J. (1998). Development of the multidimensional school anger inventory for males. Psychology in the Schools, 35, 1-15 https://doi.org/10.1002/1520-6807

Spielberger, C. D. (1988). State-Trait anger expression inventory: Psychological assessment resources. Odessa, Research edition.

Spielberger, C. D., Johnson, E. H., Russell, S. F. ve Crane, R. J. (1985). The experience and expression of anger. Construction and validation of an anger expression scale. M. A. Chesney ve R. H. Rosenman (Yay. haz.). Anger and hostility in cardiovascular and behavioral disorders, 5-30. Washington, DC: Hemisphere.

Tarshis, P. T. (2010). Living with Peer Pressure and Bullying, New York: Maple-Vail Book Manufacturing Group.

Taylor, J. L ve Novaco, R. W. (2005). Anger treatment for people with developmental disabilities: A theory, evidence and manual based approach. West Sussex, England, John Wiley \& Sons Ltd

Thoits, P. (1985). Social support and psychological well-being: theoretical possibilities. I. G. Sarason, B. R. Sarason (Yay. haz.). Social support: theory, research and applications, içinde (ss. 51-72). Dordrecht, Netherlands: Martinus Nijhoff Publishers.

Torestad, B. (1990). What is anger provoking? A psychophysical study of percevied causes of anger. Agressive Behavior, 16, 9-26. https://doi.org/10.1002/1098-2337

Uchino, B. N. (2009). Understanding the links between social support and physical health: A life-span perspective with emphasis on the separability of perceived and received 
support. Perspectives on Psychological Science, 4(3), 236- 255. doi:10.1111/ j.17456924.2009.01122.x

Uchino, B. N, Cacioppo, J. T ve Kiecolt-Glaser, J. K. (1996) The relationship between social support and physiological processes: a review with emphasis on underlying mechanisms and implications for health. Psychological Bulletin, 119(3), 488-531.

Vanderdrift, L. E., Lehmiller, J. J. ve Kelly, J. R. (2012). Commitment in friends with benefits relationships: Implications for relational and safe-sex outcomes. Personal Relationships, 19, 1-13. doi: 10.1111/j.1475-6811.2010.01324.x

Zimet, G., Dahlem, N., Zimet, S. ve Farley, G. (1988). The multidimensional scale of perceived social support. Journal of Personality Assessement, 52, 30-41 doi.org/10.1207/ s15327752jpa5201_2

\section{Extended Abstract \\ Introduction}

Adolescence involves critical developmental processes and life cycle in human life. It has therefore been the subject of research in the social sciences. Adolescents may wish greater independence and responsibility because one of the development tasks of this period is the search for identity and independence initiatives. Therefore, the emotional changes and characteristics of adolescents can lead to increased conflict. In order to establish healthy relationships with the environment, it is very important for them to express their feelings. One of the most important emotions to express in order to establish healthy relationships is anger (Fryxell \& Smith, 2000; Smith, Furlong \& Boman, 2006).

There are many anger-related problems in social life. How students, especially in adolescence, should express their anger is an issue that needs to be addressed. Because negative or misrepresentation of anger causes many adaptation problems (Feindler \& Engel, 2011). There are many ways to express anger negatively. These are attitudes such as verbal violence, nonverbal violence, repressed anger, passive aggressive behavior, complaining, physical aggression, and displacement (Elliot \& Smith, 2017).

Adolescents, trying to survive in society, strive to accomplish those tasks. Foremost among these is social anxiety which is the most important factor in controlling anger. Getting social support in coping with social anxiety is important to the adolescent (Cohen \& Wills, 1985). Social support has two different dimensions in the form of received and provided social support. Received social support is supported by family, friends, and their immediate circle in order for the individual to be able to prove their own existence (Gottlieb \& Bergen, 2010). Sources of support are not interchangeable in received social support (Uchino, 2009).

Relationships with friends hold an important place in expressing anger (Cohen \& Wills, 1985). Adolescents feel the need to be involved and to be accepted by a group. Therefore, they attach importance to friendship (Bee \& Boyd, 2009, p. 622). Sometimes they give in peer pressure because they don't want to be rejected by their friends (Blakemore \& Mills, 2014; De Guzman, 2009, p. 12). Peer pressure may include the negative behavior of an adolescent or group in various ways, such as using drugs, encouraging negative or incompatible behavior, dressing the same model, listening to the same music, encouraging sexual activities and nonfamily fun (Goel \& Malik, 2017; Maxwell, 2002; Santor, Messervey \& Kusumakar, 2000; Shilts, 1991).

When literature and studies are examined, it is observed that the way adolescents express their anger is an important variable in their social life. Anger management is a very difficult situation for adolescents (Philips-Hershey \& Kanagy, 1996). Therefore, it is important to understand the anger and anger responses of adolescent students and to reveal the consequences of this. Accordingly, the purpose of our research is to examine how adolescents express their anger positively at school. In order to achieve this goal, the following questions were answered:

- Is there a relationship between the way adolescents express anger at school, peer pressure and their perceptions of friendships? 
- Do adolescents' peer pressures, received sources of social support, commitment in their friendships and genders predict the way they express anger at school?

- Does the way adolescents express anger at school differ according to their gender?

- Does the way adolescents express anger at school differ according to the sources of social support they receive?

\section{Method}

Relational screening model was used in the research. The dependent variable of our research is the way adolescents express positive anger. Independent variables were peer pressure, received social support, friendship commitment and gender. This study was conducted on ninth and tenth grade students at a state-owned secondary school in Adana and Hatay province. The answers given by 544 students were taken into account during the research process. Of these students, 326 (59.92\%) were girls and 218 (40.08\%) were boys. In order to collect data, "multidimensional school anger inventory", "friendship commitment scale", "peer pressure scale" and demographic data form were used. T-test, correlation, multiple regression, descriptive, variance analysis were used for the analysis of the data.

\section{Result and Discussion}

The results show that there are positive relationships between expressing anger in school and peer pressure and friendship commitment. In addition, there is a significant negative relationship between peer pressure and friendship commitment. All four independent variables are meaningful predictors in explaining the variance of adolescents' scores for expressing anger positively. Peer pressure, then perceived sources of social support, peer pressure, and gender variability are the main reasons for expressing anger. Although there are differences between boys and girls in expressing anger positively, this is not a significant level. Those who do not receive social support from anyone can express their anger more positively than those who say they receive social support from family and friends. In addition, those who receive social support from family and friends are more successful in expressing their anger positively than those who receive social support from family alone.

The reasons why there is a positive relationship between peer pressure and expressing anger positively is because there may be need for acceptance and being influenced by peer in higher socio-economic status, and peer pressure can sometimes be directed towards positive behaviors. It is thought that the quality of friendship commitments may be effective in predicting low levels of expressing anger positively. Furthermore, the reasons why adolescents who do not receive social support from anyone express their anger more positively than those who receive social support can be interpreted as thinking of support from the environmentespecially the family-as intervention and as wanting to act independently. On the other hand, the fact that the gender variable does not have a significant effect on expressing anger positively can be interpreted as the events and inhibitions experienced during adolescence are not specific to that period. 